\title{
Epigenetic Regulation by Bisphenol A as a Neuronal Morphogen
}

\author{
Matsuura K, Yamazoe R, Maruoka H and Shimoke $\mathbf{K}^{*}$ \\ Department of Life Science and Biotechnology, Materials and Bioengineering, High Technology Research Core (HRC), Kansai University, Yamatecho, Suita, Osaka, \\ Japan
}

"Corresponding author: Shimoke K, Department of Life Science and Biotechnology, Faculty of Chemistry, Materials and Bioengineering, High Technology Research Core (HRC), Kansai University, Yamatecho, Suita, Osaka, Japan, Tel: +81-6-6330-3770; E-mail: shimoke@kansai-u.ac.jp

Received date: July 25, 2017; Accepted date: August 5, 2017; Published date: August 10, 2017

Copyright: (c) 2017 Matsuura K, et al. This is an open-access article distributed under the terms of the Creative Commons Attribution License, which permits unrestricted use, distribution and reproduction in any medium, provided the original author and source are credited.

Citation: Matsuura K, Yamazoe R, Maruoka H, Shimoke K (2017) Epigenetic Regulation by Bisphenol A as a Neuronal Morphogen. J Bioengineer \& Biomedical Sci 7: e128. doi:10.4172/2155-9538.1000e128

\section{Editorial}

Synthetic compounds are having epigenetic or cellular reprogramming impact which is an established truth. Commercial use of such synthetic compounds should be analyzed for health impact on human being before redundant use, especially related to food items. Bisphenol A (BPA) is one such compound which major used in the plastic industry and also for generation of epoxy compounds. There is an abundant use of this compound in packaging industry which includes canning food items. Therefore, thorough investigation is required regarding the impact of the compound on our health. Literature evidence is available related to the harmful effect of Bisphenol A, which generally acts as endocrine disruptors. Moreover, impact of BPA on male and female reproduction, neurological and behavioral issues have been proved earlier. It was found to have carcinogenic activity on human. Such impact is done generally through alteration of the epigenetic regulation of the DNA methylation. Endocrine disrupting chemicals (EDCs) promote a female-inducing phenotype in organs comprised of genital cells. Examples include miniaturized male genitalia and uterine cell death. The effects of EDCs are speculated to be due to their action as female-determinative factors through inhibition of endogenous male hormone receptors. Bisphenol A (BPA) is an endocrine disrupting chemical (EDC) that can cross the brain-brood barrier (BBB) due to its hydrophobic character [1], and thus, neurons or glial cells can be affected in a BPA-specific manner. We have found that EDC which involves alkylphenol group as same as BPA can cause apoptosis in PC12 cells [2]. This mechanism was classified as endoplasmic stress (ER)-mediated apoptosis, due to involvement of accumulation of unfolded proteins and upregulation of glucose-regulated protein 78 (GRP78), a marker of ER stress [3]. In addition, an ordinary apoptosis mechanism was also present $[4,5]$. We also found that GRP78 was upregulated following treatment of the cells with nerve growth factor (NGF), despite NGF promoting cell viability $[6,7]$. This result suggests that GRP78 may serve as a functional protein in ER stress prevention, as well as a marker of ER stress. In addition to functional prevention of ER stress-mediated apoptosis, NGF promotes neurite extension in PC12 cells [8]. This phenomenon is necessary for physiological development of the embryo and preservation of mature neurons. Surprisingly, we found that BPA mimicked the function of NGF, suggesting that endogenous hormonal ligands are inhibited by BPA. A morphological analysis showed that the shape of BPA-treated cells was the same as that of forskolin-treated cells (manuscript in preparation). Forskolin promotes neuronal differentiation via the PKA-CREB pathway, in which PKA activated by forskolin phosphorylates CREB, which then binds to CRE sites in various gene promoters (manuscript in preparation). This process also involves specific acetylation of histones, which also induces the expression of nur77 gene, one of the immediate early gene (manuscript in preparation). Thus, we suggest that intracellular signaling caused by BPA is similar to forskolin-induced signaling, while BPA shares a binding site on a nuclear receptor with endogenous hormones. A further study is needed to examine whether a BPA-mediated signal leading to neurite extension prevents a harmful effect of BPA on neurons.

\section{Grant Information}

This work was supported, in part, by grants-in-aid for scientific research, SENRYAKU (2013-2017) and KAKENHI (16K00626), from MEXT (Ministry of Education, Culture, Sports, Science and Technology of Japan).

\section{References}

1. Nickel S, Mahringer A (2014) The xenoestrogens ethinylestradiol and bisphenol A regulate BCRP at the blood-brain barrier of rats. Xenobiotica 44: 1046-1054.

2. Kusunoki T, Shimoke K, Komatsubara S, Kishi S, Ikeuchi T (2008) pNonylphenol induces endoplasmic reticulum stress-mediated apoptosis in neuronally differentiated PC12 cells. Neurosci Lett 431: 256-261.

3. Kozutsumi Y, Segal M, Normington K, Gething MJ, Sambrook J (1988) The presence of malfolded proteins in the endoplasmic reticulum signals the induction of glucose-regulated proteins. Nature 332: 462-464.

4. Watanabe-Fukunaga R, Brannan CI, Copeland NG, Jenkins NA, Nagata S (1992) Lymphoproliferation disorder in mice explained by defects in Fas antigen that mediates apoptosis. Nature $356: 314-317$.

5. Shimoke K, Kubo T, Numakawa T, Abiru Y, Enokido Y, et al. (1997) Involvement of phosphatidylinositol-3 kinase in prevention of low $\mathrm{K}(+)$ induced apoptosis of cerebellar granule neurons. Dev Brain Res 101: 197-206.

6. Shimoke K, Chiba H (2001) Nerve growth factor prevents 1-methyl-4phenyl-1,2,3,6-tetrahydropyridine-induced cell death via the Akt pathway by suppressing caspase-3-like activity using PC12 cells: relevance to therapeutical application for Parkinson's disease. J Neurosci Res 63: 402-409.

7. Shimoke K, Kishi S, Utsumi T, Shimamura Y, Sasaya H, et al. (2005) NGFinduced phosphatidylinositol 3-kinase signaling pathway prevents thapsigargin-triggered ER stress-mediated apoptosis in PC12 cells. Neurosci Lett 389: 124-128.

8. Greene LA (1978) Nerve growth factor prevents the death and stimulates the neuronal differentiation of clonal PC12 pheochromocytoma cells in serum-free medium. J Cell Biol 78: 747-755. 